\title{
MARINE RADIOCARBON RESERVOIR VALUES IN SOUTHERN CALIFORNIA ESTUARIES: INTERSPECIES, LATITUDINAL, AND INTERANNUAL VARIABILITY
}

\author{
James R Holmquist ${ }^{1} \bullet$ Laura Reynolds $^{2} \bullet$ Lauren N Brown $^{3} \bullet$ John R Southon $^{4} \bullet$ \\ Alexander R Simms² • Glen M MacDonald ${ }^{1,3,5}$
}

\begin{abstract}
Many studies use radiocarbon dates on estuarine shell material to build age-depth models of sediment accumulation in estuaries in California, USA. Marine ${ }^{14} \mathrm{C}$ ages are typically older than dates from contemporaneous terrestrial carbon and local offsets $(\Delta \mathrm{R})$ from the global average marine offset need to be calculated to ensure the accuracy of calibrated dates. We used accelerator mass spectrometry (AMS) ${ }^{14} \mathrm{C}$ dating on 40 pre-1950 salt marsh snail and clam shells previously collected from four California estuaries. The average $\Delta \mathrm{R}$ and standard deviation of $217 \pm 129{ }^{14} \mathrm{C}$ yr is consistent with previous calculations using mixed estuarine and marine samples, although the standard deviation and resulting age uncertainty was higher for our estuarine calculations than previous studies. There was a slight but significant difference $(p=0.024)$ in $\Delta \mathrm{R}$ between epifaunal snails $\left(\Delta R=171 \pm 154{ }^{14} \mathrm{C}\right.$ yr $)$ and infaunal clams $\left(\Delta R=263 \pm 77{ }^{14} \mathrm{C}\right.$ yr $)$, as well as between samples from individual estuaries. However, a closer examination of the data shows that even for the same species, at the same estuary, $\Delta \mathrm{R}$ can vary as much as $\sim 500{ }^{14} \mathrm{C}$ yr. In some cases, the bulk of this variation occurs between samples collected by different collectors at different times, potentially indicating time dependence in carbon sources and $\Delta \mathrm{R}$ variation. These variations could also be attributed to differences in collection location within a single estuary and resulting spatial differences in carbon sources. Intertidal specimens located in the high marsh may have lower $\Delta \mathrm{R}$ than fully marine counterparts because of increased terrestrial ${ }^{14} \mathrm{C}$ input. The large variations in $\Delta \mathrm{R}$ here highlight the need for conservative chronological interpretations, as well as the assumption of wide uncertainties, when dating samples from estuarine sources.
\end{abstract}

\section{INTRODUCTION}

Radiocarbon dating of carbonate material from marine shells is a vital tool for paleoenvironmental studies (Cole and Liu 1994; Malamud-Roam et al. 2006; Hassan et al. 2009; Enkin et al. 2013; Nolte et al. 2013; Ouyang and Lee 2013). However, these types of dates are subject to the marine ${ }^{14} \mathrm{C}$ offset effect. The ${ }^{14} \mathrm{C}$ ages measured from marine organisms tend to be older than terrestrial material of the same age because of the lag in ocean-atmosphere equilibration and the upwelling of ${ }^{14} \mathrm{C}$-depleted dissolved inorganic carbon (DIC) into the ocean mixed layer. Marine calibration curves have been developed to address this problem using dating of known-age carbonates and a random-walk statistical design (Reimer et al. 2013). Marine13, the oceanic calibration curve, is offset from IntCal13, the terrestrial calibration curve, by an average of $350 \mathrm{yr}$ from 0 to $10,500 \mathrm{yr}$ BP (Reimer et al. 2013). However, there is substantial local variation in the marine offset due to differences in water mass sources and degrees of upwelling, among other factors. Calculating the difference between local marine ${ }^{14} \mathrm{C}$ ages and the marine ${ }^{14} \mathrm{C}$ calibration curve $(\Delta \mathrm{R})$ is vital to accurately address this variability.

Surface waters off of North America's Pacific coast tend to have higher $\Delta \mathrm{R}$ values than the standard marine calibration because of strong upwelling caused by the western deflection of the California Current as it moves south from British Columbia to Baja California. Latitudinal variation in upwelling strength causes a tendency for poleward waters to have higher $\Delta \mathrm{R}$ than equatorial waters (Bard 1998). Temporal variation in upwelling strength has been used to explain the large range in $\Delta \mathrm{R}$ observed throughout the Holocene from studies of paired marine and terrestrial material along the California coast (Kennett et al. 1997; Ingram 1998; Hendy et al. 2013).

1. University of California, Los Angeles, Institute of the Environment and Sustainability, La Kretz Hall, Suite 300, Box 951496, Los Angeles, CA 90095-1496, USA.

2. University of California, Santa Barbara, Department of Earth Science, 1006 Webb Hall, Santa Barbara, CA 93106, USA.

3. University of California, Los Angeles, Department of Geography, 1255 Bunche Hall, Box 951524, Los Angeles, CA 90095, USA.

4. Keck-CCAMS Group, Earth System Science Department, B321 Croul Hall, University of California, Irvine, CA 926973100, USA.

5. Corresponding author. Email: macdonal@geog.ucla.edu.

Proceedings of the 1st International Radiocarbon in the Environment Conference 18-22 August 2014, Queen's University Belfast, Belfast, Northern Ireland, UK

Edited by Evelyn Keaveney and Paula Reimer 
Previous studies have calculated $\Delta \mathrm{R}$ in southern California by either dating known material from museum collections (Berger et al. 1966; Robinson et al. 1981; Ingram and Southon 1996), or comparing marine and terrestrial ${ }^{14} \mathrm{C}$ dates in stratigraphic cores (Ingram and Southon 1996; Culleton et al. 2006; Hendy et al. 2013). Ingram and Southon (1996) synthesized existing data with original data and calculated a $\Delta \mathrm{R}$ of $220 \pm 40{ }^{14} \mathrm{C}$ yr for southern California, a slightly higher $\Delta \mathrm{R}$ for northern California and the San Francisco Bay $\left(\Delta \mathrm{R}=290 \pm 35\right.$ and $365 \pm 35{ }^{14} \mathrm{C}$ yr, respectively), and a much higher $\Delta \mathrm{R}$ for the Gulf of California $\left(\Delta \mathrm{R}=410 \pm 40{ }^{14} \mathrm{C} \mathrm{yr}\right)$.

Known-age studies of $\Delta \mathrm{R}$ in southern California include both marine and estuarine specimens (Berger et al. 1966; Robinson and Thompson 1981; Ingram and Southon 1996; Figure 1). However, ${ }^{14} \mathrm{C}$ uptake by organisms in estuarine environments may be fundamentally different from that in open marine systems because estuarine systems include carbon from marine, terrestrial, and freshwater inputs. Ingram and Southon (1996) observed a range in $\Delta \mathrm{R}$ of $300{ }^{14} \mathrm{C} \mathrm{yr}$ for the San Francisco Estuary due to differences in marine versus freshwater input. Additionally, the shallow water of tidal marshes may reach equilibrium with the atmosphere much faster than deep marine systems.

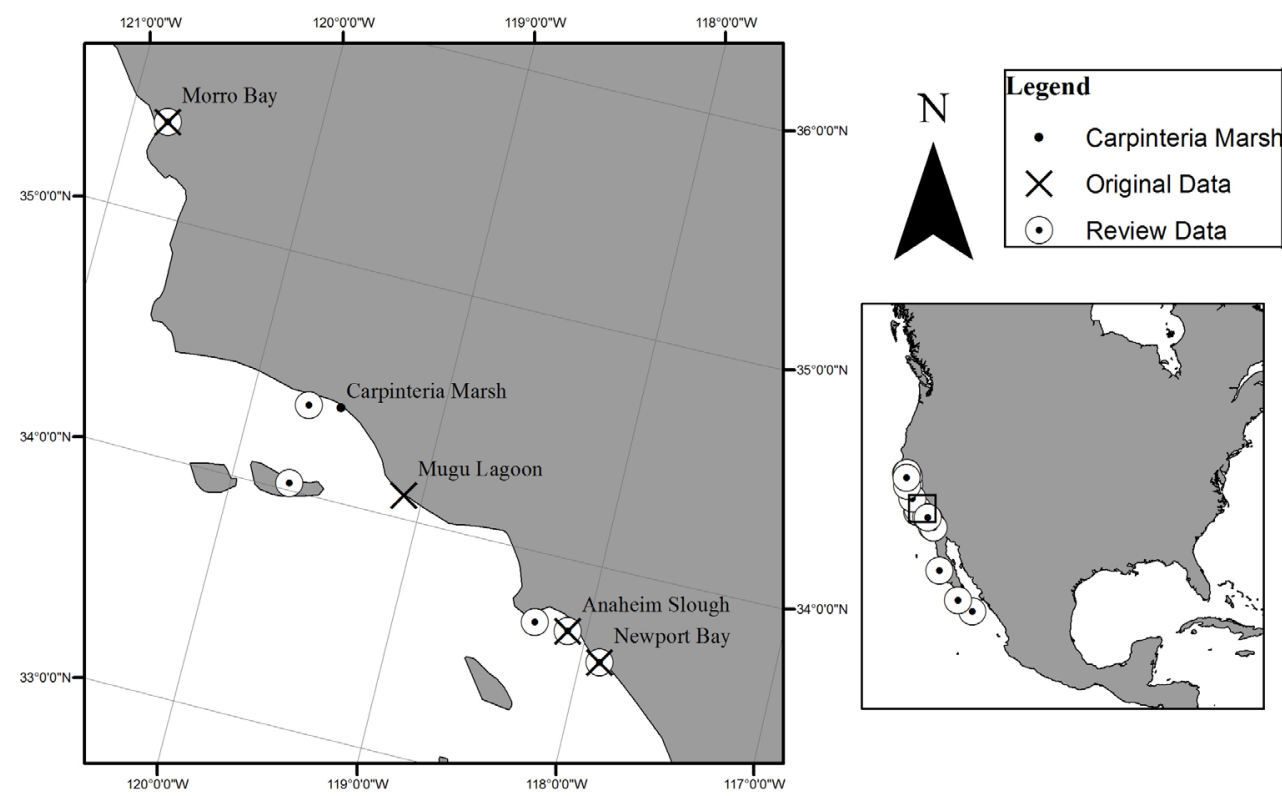

Figure 1 Map of study sites, review data (http://calib.qub.ac.uk/marine/), and other locations mentioned in the text

Studies on the behavior and lifecycles of gastropods and bivalves living in estuaries indicate that these organisms may incorporate carbon into their shells from multiple sources. In a study of $\Delta R$ of gastropods in Caution Bay, Papua New Guinea, members of the Strombideae family accumulated more ${ }^{14} \mathrm{C}$-depleted carbonate because they burrowed in carbonate-rich mud, while Cerithidea largillierti had the most variation in $\Delta \mathrm{R}$ because they absorbed ${ }^{14} \mathrm{C}$ from both enriched and depleted sources (Petchey et al. 2012). Ingram and Southon (1996) noted $\Delta \mathrm{R}$ differences between species and hypothesized that preferential feeding could influence shell isotopic ratio. However, in the majority of marine mollusks, localized differences in DIC account for more variability in $\Delta \mathrm{R}$ than diet

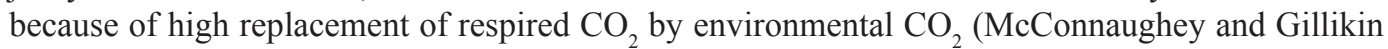
2008). A study from Carpinteria Marsh concluded that ${ }^{13} \mathrm{C}$ depletion in estuarine invertebrates was much more similar to offshore plankton values than to terrestrial invertebrates (Page 1997). 
Marine shells are present in many marsh sediment cores, have been used historically in age-depth models, and continue to serve as an important chronological control in estuarine system studies (Mudie and Byrne 1980; Brevik and Homburg 2004). Due to the current paucity of $\Delta \mathrm{R}$ values for marsh species in southern Californian estuaries, we designed a 40 -sample multispecies, multilocation study to address the following questions: (1) What is the $\Delta \mathrm{R}$ and the standard deviation for estuaries in southern California, and how does it compare to previously published values from mixed marine and estuarine data? (2) Is there a significant difference in $\Delta \mathrm{R}$ between largely epifaunal Cerithidea californica and largely infaunal marsh bivalves (Tagelus californianus and Clinocardium nuttallii)? (3) Are local differences in $\Delta \mathrm{R}$ based on differences in latitude or terrestrial carbon sources?

\section{MATERIALS AND METHODS}

Dating specimens of a known age is a common method for calculating $\Delta \mathrm{R}$ (Ingram and Southon 1996; Ascough et al. 2005a). This method has advantages over dating paired plant and carbonate samples in a sediment core. Less uncertainty is introduced in known-age studies because, at least in principle, collection dates provide an accurate age with which to compare the measured ${ }^{14} \mathrm{C}$ ages and their inherent uncertainty, rather than combining two sets of associated ${ }^{14} \mathrm{C}$ age uncertainties (Ascough et al. 2005a; Petchey et al. 2009). Unfortunately, limited material is available for such analysis because samples need to be from the mid-1950s or earlier to avoid the confounding effects of ${ }^{14} \mathrm{C}$ fallout from nuclear weapons testing (Druffel 2002; Scourse et al. 2012).

A preliminary examination of marsh species from the Los Angeles Natural History Museum (LACM) and the Santa Barbara Natural History Museum (SBNHM) indicated that Cerithidea californica and Tagelus californianus were commonly collected marsh species for which a number of samples were available for analysis (Appendix). Tagelus spp. and C. californica have been used in ${ }^{14} \mathrm{C}$ studies requiring $\Delta \mathrm{R}$ estimates (Hassan et al. 2009; Scott et al. 2011). Common estuarine sampling locations included Newport Bay, Anaheim Slough, Mugu Lagoon, and Morro Bay (Figure 1). In order to test the effect of location and species on $\Delta \mathrm{R}$, we designed a four-site, two-species, and five-replicate sampling strategy, for a total of 40 separate calculations of $\Delta R$. Ideally, we would have only compared two species across four sites; however, we were not able to find any pre-1950 specimens of Tagelus spp. for Morro Bay. Therefore, we substituted an ecologically similar clam species (Clinocardium nuttallii) and refer to the comparison as two "functional types." C. californi$c a$ are epifaunal benthic algae feeders, and T. californianus and C. nuttallii are infaunal suspension feeders.

Similar to Ingram and Southon (1996), we assume that shells from museum collections are representative of living material, at least within the 5-yr uncertainty inherent in ${ }^{14} \mathrm{C}$ calibration curves (Reimer et al. 2013). However, details regarding the collection of these samples are very limited and there is no confirmation that specimens were collected live (Appendix).

Prior estimates of $\Delta R$ are available for Newport Bay (Ingram and Southon 1996), Seal Beach near Anaheim Slough (Berger et al. 1966), and Morro Bay (Robinson and Thompson 1981), but these estimates are based on few measurements and not from the marsh species that we studied (Figure 1). We used ${ }^{14} \mathrm{C}$ ages and collection years from review data (http://calib.qub.ac.uk/marine/) to recalculate reservoir effect $(R)$ and local reservoir effect $(\Delta R)$ with Equations 1 and 2 to ensure a consistent comparison using the most current calibration curves (Reimer et al. 2013):

$$
\begin{gathered}
\mathrm{R}={ }^{14} \mathrm{C} \text { age }- \text { IntCal13[collection year] } \\
\Delta \mathrm{R}={ }^{14} \mathrm{C} \text { age }- \text { Marine13[collection year] }
\end{gathered}
$$


We used a Dremel ${ }^{\circledR}$ saw to subsample the youngest portion of each sample while minimizing the amount of destructive sampling. For Cerithidea californica, we subsampled a $\sim 0.5 \mathrm{~cm}^{-2}$ section of the inner lip near the shell's aperture. For the Tagelus californianus and Clinocardium nuttallii shells, we subsampled a $\sim 0.5-\mathrm{cm}^{-2}$ section from the ventral side of one of the two valves.

All samples were prepared, and AMS ${ }^{14} \mathrm{C}$ measurements were performed, at the University of California Irvine's Keck AMS facility. Shell subsamples were crushed into a coarse powder and leached of $50 \%$ of their mass using $\mathrm{HCl}$, resulting in a sample of $\sim 8 \mathrm{mg}$ of carbonate. Carbonate was converted into $\mathrm{CO}_{2}$ in evacuated Vacutainer ${ }^{\circledR}$ blood collection vials using phosphoric acid. $\mathrm{CO}_{2}$ was graphitized on Fe powder with hydrogen gas at $525^{\circ} \mathrm{C}$. AMS measurements of $\Delta^{14} \mathrm{C}$ were normalized to results on multiple aliquots of the NBS oxalic acid I standard; known-age coral secondary standards and ${ }^{14} \mathrm{C}$-free calcite blanks were prepared and run with the unknowns.

We removed two outlier samples from the initial data set that were much older than could be explained by differences in surface water age and were most likely reworked material (Table 1). We replaced the outliers with two additional specimens from the same site and species, but from different collections.

Table 1 Specimen information, AMS ${ }^{14} \mathrm{C}$ results for specimens used in this study, as well as $\mathrm{R}$ and $\Delta \mathrm{R}$ calculated from IntCal13 and Marine13 (Reimer et al. 2013) according to Equations 1 and 2: (a) Refers to samples that were removed as outliers, because they were likely from reworked material and ${ }^{(b)}$ refers to replacements for those outliers.

\begin{tabular}{|c|c|c|c|c|c|c|c|c|}
\hline Collection ID & Species & Location & $\begin{array}{l}\text { Collect- } \\
\text { ed year }\end{array}$ & $\begin{array}{l}\text { UCIAMS } \\
\#\end{array}$ & $\begin{array}{l}\Delta^{14} \mathrm{C} \\
(\%)\end{array}$ & $\begin{array}{l}{ }^{14} \mathrm{C} \text { age } \\
\mathrm{BP}\end{array}$ & $\mathrm{R}$ & $\Delta \mathrm{R}$ \\
\hline LACM 113265 & Cerithidea & Anaheim Slough & 1948 & 138737 & $-74.50 \pm 1.78$ & $620 \pm 20$ & 421 & 151 \\
\hline ACM 113265 & Cerithidea & Slough & 1948 & 8738 & -75.9 & & 436 & 166 \\
\hline ACM 113265 & Cerithidea & Slough & 1948 & 138739 & -75.39 & & 431 & 161 \\
\hline ACM 42-3.2 & Cerithidea & ugh & 1942 & 138735 & -95.7 & 15 & 638 & 350 \\
\hline LACM 42-3.2 & Cerithidea & & 942 & 138736 & -82.9 & & 523 & 235 \\
\hline & Cerithidea & & 1 & 10 & -61 . & & 306 & 36 \\
\hline 95 & Cerithidea & & 1 & 138741 & -64 & & 331 & 61 \\
\hline 1271 & ithidea & & & 12 & -60 & & 312 & 36 \\
\hline 271 & rithidea & & & 138743 & -57. & & 287 & 11 \\
\hline 71 & Cerithidea & & & & & & 342 & 66 \\
\hline 54 & Cerithidea & & & 13 & -57 & & 343 & 24 \\
\hline & Cerithidea & & & & & & 403 & 84 \\
\hline 4 & Cerithidea & & & & & & 383 & 64 \\
\hline & Cerithidea & & & & & & 816 & 513 \\
\hline & hidea & & & & & & 776 & 473 \\
\hline & Cerithidea & & & & -51 & & 253 & -35 \\
\hline 22.1 & Cerithidea & & & & -195. & & - & - \\
\hline & Cerithidea & & 19 & $7^{(\mathrm{b})}$ & -77 & & 451 & 181 \\
\hline & Cerithidea & & & & & & 566 & 296 \\
\hline & hidea & & & & & & 546 & 276 \\
\hline LAC & Cerithidea & & & & & & 546 & 276 \\
\hline 062 & Clinocardium & & & & -78.2 & & 483 & 195 \\
\hline & Clinocardium & Mor & & 138756 & -93.8 & & 597 & 321 \\
\hline & Clinocardium & & & & -87.0 & & 362 & 86 \\
\hline & Clinocardium & & & & & & 437 & 161 \\
\hline & Clinocardium & Morro Bay & & 138759 & $-87.09 \pm 1.71$ & $605 \pm 20$ & 417 & 141 \\
\hline LACM 38-174 & Tagelus & Anaheim Slough & 1938 & $138760^{(a)}$ & $-518.95 \pm 1.29$ & $5880 \pm 25$ & — & \\
\hline
\end{tabular}


Table 1 (Continued).

\begin{tabular}{|c|c|c|c|c|c|c|c|c|}
\hline Collection ID & Species & Location & $\begin{array}{l}\text { Collect- } \\
\text { ed year }\end{array}$ & $\begin{array}{l}\text { UCIAMS } \\
\#\end{array}$ & $\begin{array}{l}\Delta^{14} \mathrm{C} \\
(\%)\end{array}$ & $\begin{array}{l}{ }^{14} \mathrm{C} \text { age } \\
\mathrm{BP}\end{array}$ & $\mathrm{R}$ & $\Delta \mathrm{R}$ \\
\hline LACM 116692 & Tagelus & Anaheim Slough & 1926 & 138761 & $-93.87 \pm 1.55$ & $790 \pm 15$ & 658 & 339 \\
\hline SBNHM 103958 & Tagelus & Anaheim Slough & 1918 & $138648^{(\mathrm{b})}$ & $-78.21 \pm 2.04$ & $655 \pm 20$ & 526 & 207 \\
\hline SBNHM 103958 & Tagelus & Anaheim Slough & 1918 & 138762 & $-87.01 \pm 1.56$ & $730 \pm 15$ & 601 & 282 \\
\hline SBNHM 103958 & Tagelus & Anaheim Slough & 1918 & 138763 & $-86.44 \pm 1.60$ & $725 \pm 15$ & 596 & 277 \\
\hline SBNHM 103958 & Tagelus & Anaheim Slough & 1918 & 138764 & $-87.09 \pm 1.71$ & $730 \pm 20$ & 601 & 282 \\
\hline LACM 18865 & Tagelus & Mugu Lagoon & 1923 & 138765 & $-101.55 \pm 1.67$ & $860 \pm 15$ & 728 & 409 \\
\hline LACM 18865 & Tagelus & Mugu Lagoon & 1923 & 138766 & $-90.79 \pm 1.55$ & $765 \pm 15$ & 633 & 314 \\
\hline LACM 64593 & Tagelus & Mugu Lagoon & 1935 & 138767 & $-86.45 \pm 1.63$ & $725 \pm 15$ & 571 & 268 \\
\hline LACM 64593 & Tagelus & Mugu Lagoon & 1935 & 138768 & $-96.65 \pm 1.73$ & $815 \pm 20$ & 661 & 358 \\
\hline LACM 64593 & Tagelus & Mugu Lagoon & 1935 & 138769 & $-92.00 \pm 1.58$ & $775 \pm 15$ & 621 & 318 \\
\hline LACM 64591 & Tagelus & Newport Bay & 1936 & 138649 & $-87.05 \pm 2.15$ & $730 \pm 20$ & 576 & 273 \\
\hline LACM 64591 & Tagelus & Newport Bay & 1936 & 138650 & $-84.86 \pm 2.02$ & $710 \pm 20$ & 556 & 253 \\
\hline LACM 64591 & Tagelus & Newport Bay & 1936 & 138651 & $-82.59 \pm 2.03$ & $690 \pm 20$ & 536 & 233 \\
\hline SBNHM 115574 & Tagelus & & 1948 & 138652 & $-87.81 \pm 2.07$ & $740 \pm 20$ & 541 & 271 \\
\hline SBNHM 115574 & Tagelus & Newport Bay & 1948 & 138653 & $-87.95 \pm 1.95$ & $740 \pm 20$ & 541 & 271 \\
\hline
\end{tabular}

We used a two-tailed, unpaired $t$ test to determine the significance of functional type (epifaunal versus infaunal) on $\Delta \mathrm{R}$. We also used analysis of variance (ANOVA) with site as the independent variable and $\Delta R$ as the dependent variable to determine if location contributed significantly to $\Delta R$ variability. All statistics were calculated using "R" software (R Core Development Team 2014).

\section{RESULTS AND DISCUSSIONS}

In 39 out of 40 measurements, $\Delta \mathrm{R}$ was positive, indicating that more shell carbonate originates from ${ }^{14} \mathrm{C}$-depleted sources than predicted by global averages (Table 1; Figure 2). $\Delta \mathrm{R}$ ranged from -35 to $513{ }^{14} \mathrm{C}$ yr (Table 2). The average $\Delta \mathrm{R}$ of $217 \pm 129{ }^{14} \mathrm{C}$ yr measured in our 40 specimens (Table 2 ) is within error of previous estimates for both estuarine and marine shells $\left(220 \pm 40{ }^{14} \mathrm{C} \mathrm{yr}\right.$; Ingram and Southon 1996). The range of $\Delta \mathrm{R}$ that we calculated fits within the pattern and variability observed previously along the California coast and is lower than estimates from San Francisco Bay (Figure 3).

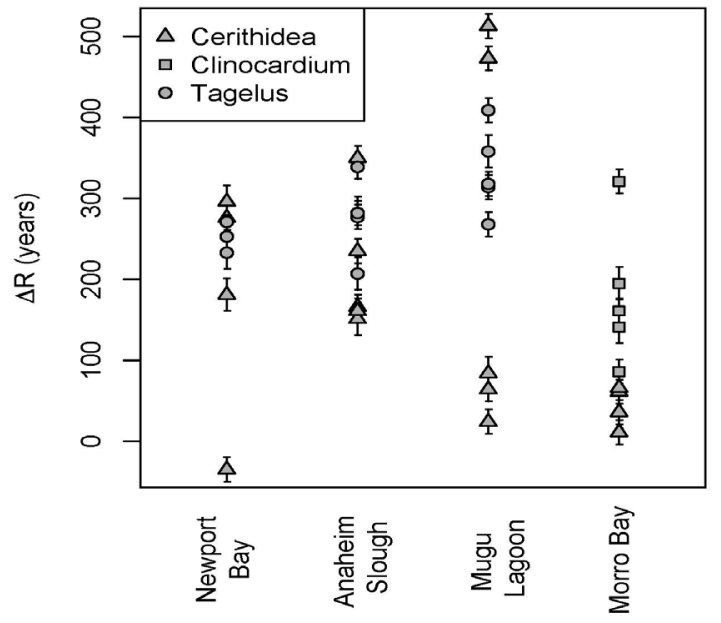

Figure $2 \Delta R$ by site and species along with associated ${ }^{14} \mathrm{C}$ age error bars. 
Table 2 Summary of $\Delta \mathrm{R}$ means, standard deviation, minimum and maximum by site, species, and functional type for original data presented in this study.

\begin{tabular}{lrlcrl}
\hline Category & \multicolumn{1}{c}{$n$} & Average $\Delta \mathrm{R}$ & \pm stand. dev. & Min & Max \\
\hline Cerithidea californica & 20 & 171 & 154 & -35 & 513 \\
Clinocardium nuttallii & 5 & 181 & 88 & 86 & 321 \\
Tagelus californianus & 15 & 290 & 51 & 207 & 409 \\
Total bivalve & 20 & 263 & 77 & 86 & 409 \\
Anaheim Slough & 10 & 245 & 72 & 151 & 350 \\
Morro Bay & 10 & 111 & 95 & 11 & 321 \\
Point Mugu & 10 & 283 & 172 & 24 & 513 \\
Upper Newport Bay & 10 & 230 & 98 & -35 & 296 \\
Total & $\mathbf{4 0}$ & $\mathbf{2 1 7}$ & $\mathbf{1 2 9}$ & $\mathbf{- 3 5}$ & $\mathbf{5 1 3}$ \\
\hline
\end{tabular}

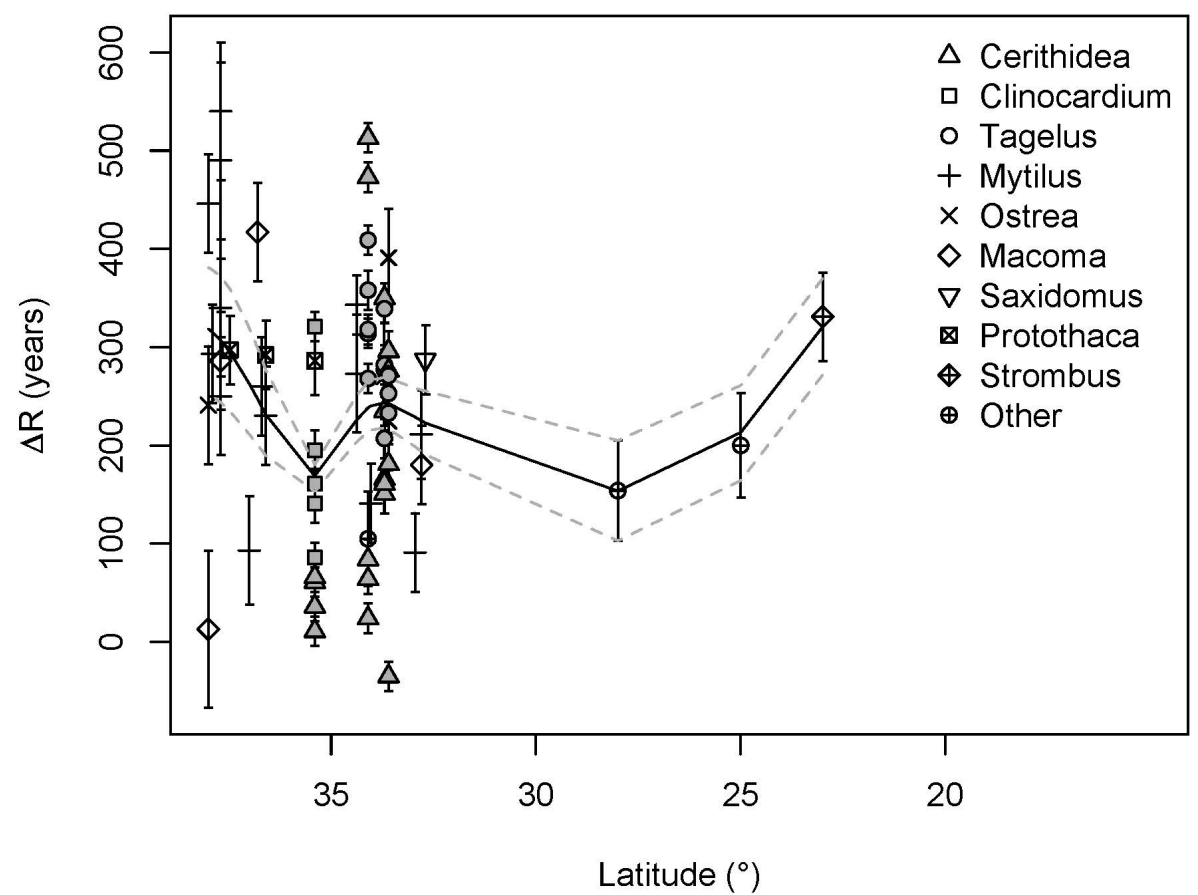

Figure $3 \Delta R$ values from this study by latitude, with associated ${ }^{14} \mathrm{C}$ age error, compared to previous data from the Pacific coasts of California and Baja California (Berger et al. 1966; Robinson et al. 1981; Ingram and Southon 1996). The black line is a spline of the $\Delta R$ means and the gray lines are splines of the minimum and maximum of the measurements. An online database (http://calib.qub.ac.uk/marine) was used as a resource to compile this review.

We observe a slight but significant difference between Cerithidea californica and marsh clams $(p=0.024$; Table 3$)$. C. californica has a lower average $\Delta \mathrm{R}$, but a much larger standard deviation (Table 2). DIC is the dominant determinate of isotopic ratios in marine shells (McConnaughey and Gillikin 2008), and the differences in the mean and variance of $\Delta \mathrm{R}$ may reflect differing ambient DIC conditions experienced by epifaunal snails (C. californica) and infaunal clams (Tagelus californianus and Clinocardium nuttallii). Some previous studies have shown that deposit feeders can have greater deviations of $\Delta \mathrm{R}$ in comparison to suspension feeders possibly because of preferential consumption habits (Petchey et al. 2012), while other researchers report no significant differences in $\Delta \mathrm{R}$ between species and position in the intertidal zone (Ascough et al. 2005b). 
Table 3 Summary of statistics for an unpaired $t$ test with functional type as the independent variable, as well as an ANOVA with site as the independent variable, and $\Delta \mathrm{R}$ as the dependent variable.

\begin{tabular}{llcl}
\hline Test & Model & $d f$ & $p$ value \\
\hline$t$ test & $\Delta \mathrm{R} \sim$ Functional Type & 27.9 & 0.024 \\
ANOVA & $\Delta \mathrm{R} \sim$ Location & 3 & 0.014 \\
\hline
\end{tabular}

There was also a slight but significant difference in $\Delta \mathrm{R}$ based on location ( $p=0.014$; Table 3 ). Mugu Lagoon had the highest standard deviation and the highest maximum $\Delta \mathrm{R}$ (Figure 2; Table 2). The locations all have similar bedrock characteristics and none contain prominent limestone outcrops directly upland in their catchments (Jennings et al. 2010), although the Western Transverse Ranges, which source Mugu Lagoon, are known to contain tufa and travertine deposits suggesting the presence of older carbon in the surface waters (Boles 2004; Ibarra et al. 2014).

A closer inspection of the data shows that some of the variability in $\Delta \mathrm{R}$ may be due to the fact that individuals collected at different times, or from slightly different places within an estuary, were combined to form a set of five replicates. In four cases, the maximum variation in $\Delta \mathrm{R}$ measured in a single species from a single marsh resulted from samples from different collections. Three of these cases occur in C. californica samples. At Anaheim Slough, the average $\Delta \mathrm{R}$ for two specimens from 1942 is $130{ }^{14} \mathrm{C}$ yr higher than three from 1948. At Mugu Lagoon, the average $\Delta \mathrm{R}$ for two specimens from 1937 is $440{ }^{14} \mathrm{C}$ yr higher than three from 1923. At Newport Bay, the average $\Delta \mathrm{R}$ from four specimens from 1948 is $290{ }^{14} \mathrm{C}$ yr higher than a single specimen from 1941. At Anaheim Slough, the $\Delta \mathrm{R}$ for a single $T$. californianus sample from 1926 is much higher than the average of four collected from 1918.

Many studies indicate that $\Delta \mathrm{R}$ for a particular location is time dependent (Heier-Nielsen et al. 1997). Extreme cases in the Pacific indicate Holocene shifts in $\Delta \mathrm{R}$ of up to $800{ }^{14} \mathrm{C}$ yr between 10,000 and $300 \mathrm{yr} \mathrm{BP}$ in the Gulf of California (Taylor et al. 2007), and $400{ }^{14} \mathrm{C} \mathrm{yr}$ between 500 and $0 \mathrm{yr}$ BP in Puget Sound and the Gulf of Georgia (Deo et al. 2004). In Jutland, Denmark, estuarine $\Delta \mathrm{R}$ ranges from -130 to $300{ }^{14} \mathrm{C}$ yr from 7300 to $1300 \mathrm{yr} \mathrm{BP}$, and was highly variable from 7300 to $5400 \mathrm{yr} \mathrm{BP}$, indicating variability in the influence of marine water and "hardwater" effects from surface runoff (Philippsen et al. 2013). In California, the temporal dependence of $\Delta \mathrm{R}$ may be due to annual or seasonal changes in upwelling (Culleton et al. 2006). In the Santa Barbara Basin, comparisons of terrestrial and planktonic foraminifera ${ }^{14} \mathrm{C}$ dates indicate that $\Delta \mathrm{R}$ varied from 80 to $350{ }^{14} \mathrm{C}$ yr since $\sim 2000$ yr BP (Hendy et al. 2013).

Along the California coast, extreme upwelling is tied to La Niña events; however, none of the collection years from anomalously old specimens coincide with extreme La Niña years (Wolter et al. 2011; Ferguson et al. 2013). Changes in $\Delta \mathrm{R}$ can also occur over time because of changes in lagoon barriers and sediment transfer dynamics (Sabatier et al. 2010), or input of ${ }^{14} \mathrm{C}$-depleted runoff (Culleton et al. 2006).

Some of the collection-specific variation in $\Delta \mathrm{R}$ may be explained by differences between intertidal and fully marine specimens. Although we do not have specific location descriptions for all samples, two sets of samples indicate material was collected from specific subenvironments within an estuary. For the Newport Bay Cerithidea californica samples, LACM 41.222.1 was collected from "intertidal sand flats along shore" while the other four samples from LACM 54135 simply list "Newport Bay" in the collection notes (ppendix). For the Anaheim Slough Tagelus californianus 
samples, LACM 38-175 was collected from "intertidal on sand and mud" while LACM 116692 simple lists "Anaheim Landing" under collection notes (Appendix). Both sets of specimens specifying intertidal collection have much lower $\Delta \mathrm{R}$ than their companions, which do not specify collection zone. If intertidal shells have lower $\Delta \mathrm{R}$ compared to fully marine shells because of increased atmospheric carbon input through ambient DIC, then the ${ }^{14} \mathrm{C}$ reservoir effect could vary by hundreds of years, even within the same estuary (Rick et al. 2012).

These findings reinforce the need to assume a broad range in error when calibrating estuarine ${ }^{14} \mathrm{C}$ dates. This study also reinforces the current consensus, that it is difficult to determine an appropriate $\Delta \mathrm{R}$ for species that tolerate a range of salinities (Reimer 2014). Future studies could specifically determine $\Delta \mathrm{R}$ spanning the intertidal zone of a single marsh for a single species to test if $\Delta \mathrm{R}$ is lower in the intertidal zone, and how much variability is potentially introduced by tidal exchange.

\section{CONCLUSION}

We used 40 pre-1950 shell samples from California estuaries to calculate local marine ${ }^{14} \mathrm{C}$ offsets, and determine the effects of species and site on the variability in $\Delta \mathrm{R}$. Our $\Delta \mathrm{R}$ estimates of $21{ }^{14} \mathrm{C} \mathrm{yr}$ on average replicated previous measurements using marine and estuarine samples. However, we did find a wider standard deviation than previously reported. $\Delta \mathrm{R}$ fluctuated based on species and site with slight statistical significance. However, it is hard to have confidence in these trends given the uncertainty introduced by variation between specimens of the same species, and from the same site, but from different collections. This variability may result from temporal variability, or may be due to spatial variability of reservoir effects between subenvironments. Although our average value of $\Delta \mathrm{R}$ in four Californian estuaries does not vary from previous estimates calculated for shells, the intraspecies and intrasite variations of up to $300{ }^{14} \mathrm{C}$ yr highlight the need for caution in dating estuarine samples.

\section{ACKNOWLEDGMENTS}

The authors would like to thank Lindsey Groves at the Los Angeles Natural History Museum, Paul Valentich-Scott, Hank Chaney, and Daniel Geiger at the Santa Barbara Natural History Museum, and Joyce Gemmell and Carole Hertz at the San Diego Natural History Museum for their maintenance of, and assistance in querying, malacology collections. US Department of Interior Geological Survey (Awards G12AC20505 and 109186) and Santa Barbara Long-Term Ecological Research (LTER) provided funding for data collection travel. We would also like to thank Katherine Hargan for assisting in sample preparation. This is a Southwest Climate Science Center contribution.

\section{REFERENCES}

Ascough P, Cook G, Dugmore A. 2005a. Methodological approaches to determining the marine radiocarbon reservoir effect. Progress in Physical Geography 29(4):532-47.

Ascough PL, Cook GT, Dugmore AJ, Scott EM, Freeman SP. 2005b. Influence of mollusk species on marine $\Delta \mathrm{R}$ determinations. Radiocarbon 47(3):433-40.

Bard E. 1998. Geochemical and geophysical implications of the radiocarbon calibration. Geochimica et Cosmochimica Acta 62(12):2025-38.

Berger R, Taylor R, Libby W. 1966. Radiocarbon content of marine shells from the California and Mexican west coast. Science 153(3738):864-6.

Boles JR. 2004. Rapid growth of meter-scale calcite speleothems in the Mission Tunnel, Santa Barbara, CA. Water-Rock Interaction. Wanty RB, Seal RR II, editors. London: Taylor \& Francis Group. p 353-6.

Brevik EC, Homburg JA. 2004. A 5000 year record of carbon sequestration from a coastal lagoon and wetland complex, Southern California, USA. Catena 57(3):221-32.

Cole KL, Liu G-W. 1994. Holocene paleoecology of an estuary on Santa Rosa Island, California. Quaternary Research 41(3):326-35.

Culleton BJ, Kennett DJ, Ingram BL, Erlandson JM, Southon JR. 2006. Intrashell radiocarbon variability in marine mollusks. Radiocarbon 48(3):387-400.

Deo JN, Stone JO, Stein JK. 2004. Building confidence in shell: variations in the marine radiocarbon reservoir correction for the Northwest Coast over the past 3,000 yr. American Antiquity 69(4):771-86.

Druffel ERM. 2002. Radiocarbon in corals: records of 
the carbon cycle, surface circulation and climate. Oceanography 15(1):122-7.

Enkin RJ, Dallimore A, Baker J, Southon JR, Ivanochko T, Lian O. 2013. A new high-resolution radiocarbon Bayesian age model of the Holocene and Late Pleistocene from core MD02-2494 and others, Effingham Inlet, British Columbia, Canada; with an application to the paleoseismic event chronology of the Cascadia Subduction Zone 1. Canadian Journal of Earth Sciences 50(7):746-60.

Ferguson J, Johnson K, Santos G, Meyer L, Tripati A 2013. Investigating $\delta^{13} \mathrm{C}$ and $\Delta^{14} \mathrm{C}$ within Mytilus californianus shells as proxies of upwelling intensity. Geochemistry, Geophysics, Geosystems 14(6):1856-65.

Hassan GS, Espinosa MA, Isla FI. 2009. Diatom-based inference model for paleosalinity reconstructions in estuaries along the northeastern coast of Argentina. Palaeogeography, Palaeoclimatology, Palaeoecology 275(1):77-91.

Heier-Nielsen S, Heinemeier J, Nielsen H, Rud N. 1997. Recent reservoir ages for Danish fjords and marine waters. Radiocarbon 37(3):875-82.

Hendy IL, Dunn L, Schimmelmann A, Pak D. 2013. Resolving varve and radiocarbon chronology differences during the last $2000 \mathrm{yr}$ in the Santa Barbara Basin sedimentary record, California. Quaternary International 310:155-68.

Ibarra Y, Corsetti FA, Cheetham MI, Feakins SJ. 2014. Were fossil spring-associated carbonates near Zaca Lake, Santa Barbara, California deposited under an ambient or thermal regime? Sedimentary Geology 30:15-25.

Ingram BL. 1998. Differences in radiocarbon age between shell and charcoal from a Holocene shellmound in northern California. Quaternary Research 49(1):102-10.

Ingram BL, Southon JR. 1996. Reservoir ages in eastern Pacific coastal and estuarine waters. Radiocarbon 38(3):573-82.

Jennings CW, Gutierrez C, Bryant W, Saucedo G, Wills C. 2010. Geologic Map of California. Sacramento: California Geological Survey.

Kennett DJ, Ingram BL, Erlandson JM, Walker P. 1997. Evidence for temporal fluctuations in marine radiocarbon reservoir ages in the Santa Barbara Channel, southern California. Journal of Archaeological Science 24(11):1051-9.

Malamud-Roam FP, Lynn Ingram B, Hughes M, Florsheim JL. 2006. Holocene paleoclimate records from a large California estuarine system and its watershed region: linking watershed climate and bay conditions. Quaternary Science Reviews 25(13):1570-98.

McConnaughey TA, Gillikin DP. 2008. Carbon isotopes in mollusk shell carbonates. Geo-Marine Letters 28(5-6):287-99.

Mudie PJ, Byrne R. 1980. Pollen evidence for historic sedimentation rates in California coastal marshes. Estuarine and Coastal Marine Science 10(3):30516.
Nolte S, Koppenaal EC, Esselink P, Dijkema KS, Schuerch M, De Groot AV, Bakker JP, Temmerman S. 2013. Measuring sedimentation in tidal marshes: a review on methods and their applicability in biogeomorphological studies. Journal of Coastal Conservation 17(3):301-25.

Ouyang X, Lee S. 2013. Carbon accumulation rates in salt marsh sediments suggest high carbon storage capacity. Biogeosciences Discussions 10(12):19,155-88.

Page H. 1997. Importance of vascular plant and algal production to macro-invertebrate consumers in a southern California salt marsh. Estuarine, Coastal and Shelf Science 45(6):823-34.

Petchey F, Allen MS, Addison DJ, Anderson A. 2009. Stability in the South Pacific surface marine ${ }^{14} \mathrm{C}$ reservoir over the last $750 \mathrm{yr}$. Evidence from American Samoa, the southern Cook Islands and the Marquesas. Journal of Archaeological Science 36(10):2234-43.

Petchey F, Ulm S, David B, McNiven IJ, Asmussen B, Tomkins H, Richards T, Rowe C, Leavesley M, Mandui H. 2012. ${ }^{14} \mathrm{C}$ marine reservoir variability in herbivores and deposit-feeding gastropods from an open coastline, Papua New Guinea. Radiocarbon 54(3-4):967-78.

Philippsen B, Olsen J, Lewis JP, Rasmussen P, Ryves DB, Knudsen KL. 2013. Mid-to late-Holocene reservoir-age variability and isotope-based palaeoenvironmental reconstruction in the Limfjord, Denmark. The Holocene 23(7):1017-27.

R Core Development Team. 2014. R: a language and environment for statistical computing. Version 2.13. 0 . Vienna: R Foundation for Statistical Computing.

Reimer PJ. 2014. Marine or estuarine radiocarbon reservoir corrections for mollusks? A case study from a medieval site in the south of England. Journal of Archaeological Science 49:142-6.

Reimer PJ, Bard E, Bayliss A, Beck JW, Blackwell PG, Bronk Ramsey C, Buck CE, Cheng H, Edwards RL, Friedrich M, Grootes PM, Guilderson TP, Haflidason H, Hajdas I, Hatté C, Heaton TJ, Hoffman DL, Hogg AG, Hughen KA, Kaiser KF, Kromer B, Manning SW, Niu M, Reimer RW, Richards DA, Scott EM, Southon JR, Staff RA, Turney CSM, van der Plicht J. 2013. IntCal13 and Marine13 radiocarbon age calibration curves $0-50,000$ years cal BP. Radiocarbon 55(4):1869-87.

Rick TC, Henkes GA, Lowery DL, Colman SM, Culleton BJ. 2012. Marine radiocarbon reservoir corrections $(\Delta R)$ for Chesapeake Bay and the Middle Atlantic Coast of North America. Quaternary Research 77(1):205-10.

Robinson SW, Thompson G. 1981. Radiocarbon corrections for marine shell dates with application to southern Pacific Northwest Coast prehistory. Syesis 14:45-57.

Sabatier P, Dezileau L, Blanchemanche P, Siant G, Condomines M, Bentaleb I, Piquès G. 2010. Holocene variations of radiocarbon reservoir ages in a Mediterranean lagoonal system. Radiocarbon 52(1):91-102. 
Scott DB, Mudie PJ, Bradshaw JS. 2011. Coastal evolution of Southern California as interpreted from benthic foraminifera, ostracodes, and pollen. Journal of Foraminiferal Research 41(3):285-307.

Scourse JD, Wanamaker Jr A, Weidman C, Heinemeier J, Reimer PJ, Butler PG, Witbaard R, Richardson CA. 2012. The marine radiocarbon bomb pulse across the temperate north Atlantic: a compilation of $\Delta{ }^{14} \mathrm{C}$ time histories from Arctica islandica growth increments. Radiocarbon 54(2):165-86.

Taylor R, Southon J, Des Lauriers MR. 2007. Holocene marine reservoir time series $\Delta \mathrm{R}$ values from Cedros Island, Baja California. Radiocarbon 49(2):899_ 904

Wolter K, Timlin MS. 2011. El Niño/Southern Oscillation behaviour since 1871 as diagnosed in an extended multivariate ENSO index (MEI. ext). International Journal of Climatology 31(7):1074-87. 